Received $\quad 15.11 .2016$

Reviewed 09.02 .2017

Accepted 28.02.2017

A - study design

B - data collection

C - statistical analysis

D - data interpretation

E - manuscript preparation

F - literature search

\section{Assessment of the relation between atmospheric precipitation and rainwater runoff for various urban surfaces}

\author{
Alicja ROMANIAK ${ }^{\mathrm{ABCDEF} \bowtie}$
}

Wrocław University of Environmental and Life Sciences, Faculty of Environmental Engineering and Geodesy, Institute of Landscape Architecture, ul. Grunwaldzka 55, 50-357 Wrocław, Poland; e-mail: alicja.romaniak@upwr.edu.pl

\begin{abstract}
For citation: Romaniak A. 2017. Assessment of the relation between atmospheric precipitation and rainwater runoff for various urban surfaces. Journal of Water and Land Development. No. 32 p. 87-94. DOI: 10.1515/jwld-20170010 .
\end{abstract}

\begin{abstract}
The relation between the diurnal sum of atmospheric precipitation and the diurnal volume of rainwater runoff from four experimental hardened surfaces was the subject of a pilot study conducted within the area of the Departmental Agro- and Hydrometeorology Observatory in Wrocław. The selection and the structure of the experimental surfaces were preceded with an inventory-taking of the coverage of hardened surfaces within a Wrocław housing estate with high-rise multifamily buildings. That estate was the second location, next to the area of the Observatory, at which the study presented here was conducted. The surfaces included in the experiment were roof surfaces $\mathrm{P}_{1}$ and $\mathrm{P}_{2}$ covered with heat-sealable roll roofing, surface APB made of gravel-filled openwork concrete plates, and tarmac surface AS. The pilot study was conducted during the period from April to November, 2014. During that period, depending on the type of experimental surface, from 81 to 87 days with atmospheric precipitation were analysed. The mean values of the rainwater runoff coefficients for the eightmonth period were $0.77,0.77,0.33$ and 0.67 for surfaces $\mathrm{P}_{1}, \mathrm{P}_{2}, \mathrm{APB}$ and AS, respectively. The range of variability of mean values of the coefficients of rainwater runoff from the experimental surfaces in a month is presented by the following relation: APB $>\mathrm{P}_{1}>\mathrm{AS}>\mathrm{P}_{2}$. The study did not reveal any direct effect of the number of rainfall days in a month on the value of the coefficient of determination describing the correlation between the diurnal sums of precipitation and the diurnal volumes of rainwater runoff.
\end{abstract}

Key words: imperviousness, precipitation, rainwater runoff coefficients, surface coverage

\section{INTRODUCTION}

Contemporary urban areas are characterised by a high share of surfaces that are impervious to precipitation waters. The percentage share of built-up and urbanised lands in Wrocław increased from $38.8 \%$ in 2006 to $41.5 \%$ in 2012 [BRW 2012]. Turning urban areas into impervious surfaces through the process of urbanisation is one of the main factors causing the appearance of excessive volumes of rainwater runoff [ARNOLD, GIBBONS 1996; JENNINGS, JARNAGIN 2002]. That phenomenon is amplified by the global climate change that causes the occurrence of weather anomalies, including intense atmospheric precipitations [BLAIR et al. 2014; LARSEN et al. 2009]. The increasing character of the phenomenon described above has had an impact on the directions of research in the field of urban hydrology, and the study of relations between the value of surface runoff and the degree of imperviousness of surfaces has become the subject-matter of numerous research works.

Studies on the volumes of rainwater runoff from selected urban areas were conducted by e.g. FERGUSON, SuCKLING [1989]; MELANEN, LAUKKANEN [1980]; BURNS et al. [2005]; METSÄRANTA et al. [2005]; VLČKOVÁ et al. [2009]; BARRON et al. 
[2011]; BZYMEK, JAROSIŃSKA [2012]; VALTANEN et al. [2014]; SillanPÄÄ, KoIVUSAlO [2015]. The choice of spatial units subjected to research resulted from differences in build-up intensity and in land use types. More precise results, in relation to specific types of surfaces, are obtained in field studies on the reduction of the volume of rainwater runoff by specific surface types [BRATTEBO, BOOTH 2003; COLlins et al. 2008; GILBERT, ClaUSEN 2006].

The analysis of the literature concerning the subject-matter of relations between the value of atmospheric precipitation influx and the volume of rainwater runoff from various surfaces indicates a need for detailed research concerning the presented issue. The research results presented in this paper permit a closer insight into the problem in question.

The paper presents the results of field measurements from the first year of an experiment conducted in the area of the Departmental Agro- and Hydrometeorology Observatory in Wrocław (Wrocław-Swojec) which is a research unit of the Wrocław University of Environmental and Life Sciences. The complexity of the problem indicates the justifiability of its more extensive study and the need of conducting the research for period of at least several years. The presented experiment, conducted on four kinds of surfaces used in urban areas, is a part of a larger experiment conducted for the purpose of identification, on its basis, the possibilities of application of a sustainable rainwater management system in urban areas. The main objective of the study was the estimation of the volume of rainwater runoff from four types of surfaces commonly used in urbanised areas.

\section{MATERIALS AND METHODS}

\section{STUDY AREA AND CHOICE OF EXPERIMENTAL SURFACES}

The experiment concerning the relations between the diurnal sums of atmospheric precipitation and the diurnal volumes of rainwater runoff, with relation to the type of surfacing, was conducted in the area of the Departmental Agro- and Hydrometeorology Observatory in Wrocław (Wrocław-Swojec) $\left(51,110^{\circ} \mathrm{N}\right.$, $\left.17,030^{\circ} \mathrm{E}\right)$, situated in south-west Poland. Analysis of the annual sums of atmospheric precipitations in Wrocław in the period of 1901-2000 indicates that their mean value for that period was $583 \mathrm{~mm}$ [DUBICKI et al. 2002] and the mean number of days with precipitation was 167 .

The experiment is conducted in conjunction with actual research conducted within the housing estate "Nowy Dwór" selected for the study. For that reason the choice of surfacing materials on which the study on the relation atmospheric precipitation-rainwater runoff is conducted was dependent on the result of the inventory of surface coverage within the research area in the Nowy Dwór Estate.

\section{TEST STATIONS}

The construction of the test stations situated in the area of the Observatory was completed in March, 2014. The test surfaces constitute representations of the actual surfaces existing within the housing estate "Nowy Dwór" - the actual slopes of the surfaces and the method of their construction have been exactly reproduced. Within each of the test surfaces an area of $1 \mathrm{~m}^{2}$ was delimited and surrounded with framing preventing the runoff of precipitation water in any undesirable direction. Only in the lowest part of each of the test surfaces the framing was left open, allowing the drainage of the entire amount of precipitation water from the test surfaces to troughs. The troughs drain the water directly to reservoirs for the accumulation of precipitation water.

\section{MEASUREMENTS}

The measurements of rainwater runoff from the test surfaces were conducted from April 2014 to November 2014 and are currently continued and taken daily at 7 a.m. Data in the form of diurnal sums of atmospheric precipitation are acquired from the Departmental Agro- and Hydrometeorology Observatory in Wrocław (Wrocław-Swojec). The measurement of the volume of atmospheric precipitation is conducted by means of the classical Hellman pluviometer. The measurements are taken twice a day, but only the diurnal sums of precipitation are taken for the analyses. The diurnal sum of precipitation relates to the range of hours started from 7:00 a.m. one day till 7:00 a.m. next day.

\section{DATA ANALYSIS}

The results of daily measurements in the form of diurnal sums of precipitation $\left(P_{d}\right)$ and diurnal volumes of rainwater runoff $\left(O_{d o s}\right)$ from the four test surfaces were collected in the form of monthly datasets. In the first stage, for each month the relations between the diurnal volumes of rainwater runoff from the test surfaces and the diurnal sums of atmospheric precipitation were analysed. Only the days with atmospheric precipitation were taken into account in the analysis. The data were presented in the form of dot charts, selecting functions providing the best description of the relations between the two datasets. For each month a regression equation was determined and the coefficient of determination $\left(R^{2}\right)$ was calculated.

Due to the random character of atmospheric precipitation, also the effect of the number of days with precipitation on the value of the coefficient of determination was analysed for each of the months of the experiment. The term 'number of days with precipitation' is used alternately with the term 'number of days on which a measurement was taken' and denoted with the symbol $n_{d P}$. Sometimes different numbers of measurement days were adopted for the four test sur- 
faces. That difference was a result of not taking into account those days on which a measurement error occurred concerning the readout of the diurnal volumes of runoff from the test surfaces.

For each day with precipitation the diurnal values of the rainwater runoff coefficient $\left(\psi_{d}\right)$ were calculated, using the following formula:

$$
\psi_{d}=\frac{O_{d o s}}{P_{d}}
$$

where: $\psi_{d}=$ coefficient of rainwater runoff from the test surfaces (diurnal value); kinds of test surface: $\mathrm{P}_{1}$ $=$ heat-sealable roll roofing (small-grain), $\mathrm{P}_{2}=$ heatsealable roll roofing (coarse-grain), APB = openwork concrete plate, AS = tarmac; $O_{d o s}=$ diurnal value of rainwater runoff $(\mathrm{mm}) ; P_{d}=$ diurnal sum of atmospheric precipitation $(\mathrm{mm})$.

The diurnal results, in the form of the sums of atmospheric precipitation and the sums of runoff from the test surfaces, were totalled up separately and the respective sums $\left(\Sigma P_{d}\right.$ and $\left.\Sigma O_{d o s}\right)$ were calculated for each element. The sums obtained in that procedure were subsequently used as the basis for the calculation of the mean values $\left(\psi_{s}\right)$ and the medians $\left(\psi_{\text {me }}\right)$ of the runoff coefficients for the month periods. The mean values of the rainwater runoff coefficients for a month were calculated according to the formula below:

$$
\psi_{s}=\frac{\Sigma O_{d o s}}{\Sigma P_{d}}
$$

where: $\psi_{s}=$ coefficient of rainwater runoff from the test surfaces (mean value calculated for a month); $\Sigma O_{d o s}=$ monthly sum of diurnal rainwater runoff from a test surface $(\mathrm{mm}) ; \Sigma P_{d}=$ monthly sum of diurnal atmospheric precipitation $(\mathrm{mm})$.

The calculations were made only for days with precipitation (Tab. 2). More accurately, the relation between the water layer that flew off a test surface and the amount of water that fell on that surface during a day with precipitation was analysed. The area of the surface for which the rainwater runoff was calculated was $1 \mathrm{~m}^{2}$.

To estimate the scale of variation of the mean values of coefficient of rainwater runoff from the test surfaces the calculations were performed separately for the consecutive months and for periods formed by their incremental combinations. The following time periods created by combining the months were specified: two-month period (April-May), three-month period (April-June), four-month period (April-July), five-month period (April-August), six-month period (April-September), seven-month period (AprilOctober), eight-month period (April-November). Created time periods permitted to estimate the minimal number of days with precipitation which is necessary for the determination of the value of the rainwater runoff coefficient. This estimation was per- formed by increasing the number of days with precipitation till the value of the coefficient of rainwater runoff approach an asymptote, which is the mean value of coefficient of rainwater runoff calculated for the period of 8 months.

As a result of the analysis of the mean monthly values and the medians of the coefficients of rainwater runoff from the test surfaces the ranges of variability of the mean monthly values of the runoff coefficients were obtained and the maximum values of these ranges were calculated.

Furthermore, for each of the test surfaces the minimum and maximum monthly values of coefficients of rainwater runoff $\left(\psi_{s \min }\right.$ and $\left.\psi_{s \max }\right)$ and the minimum and maximum monthly medians of these coefficients $\left(\psi_{\text {memin }}\right.$ and $\left.\psi_{\text {memax }}\right)$ were calculated.

After the 8-month period of the study the mean values of coefficient of rainwater runoff $\left(\psi_{s r}\right)$ were calculated. The calculations were made analogously to the calculations performed for separate months and for periods created by their incremental combinations.

\section{RESULTS}

\section{RELATIONS BETWEEN DIURNAL SUMS OF ATMOSPHERIC PRECIPITATION AND DIURNAL VOLUMES OF RUNOFF FROM TEST SURFACES}

During the 8-month period of the study the diurnal sums of precipitation fell within the range of $0.1-$ $55.2 \mathrm{~mm}$. During that period of time the highest value of $R^{2}$ (for the period of a month) was obtained for surface $\mathrm{P}_{2}\left(R^{2}=0.9998\right.$; in October $)$. Among all the test surfaces most frequently the highest values of $R^{2}$ were obtained for surface $\mathrm{P}_{2}$ (four times), while three times for surface $P_{1}$. The values of the coefficient of determination $R^{2}$ for the test surface $\mathrm{P}_{1}, \mathrm{P}_{2}, \mathrm{APB}$ and AS are presented in Table 1 . The relations between diurnal sums of runoff from test surfaces and diurnal sums of atmospheric precipitation are illustrated in Figure 1.

In the case of test surface $\mathrm{P}_{1}$ the number of days with precipitation had no effect on the value of the coefficient of determination. The highest values of $R^{2}$, close to 1 , were obtained at $n_{d P}$ equal to 9 . Those values were obtained in June and in October. A slight lower value of $R^{2}$ was obtained in August, at $n_{d P}$ of 15 $\left(R^{2}=0.9978\right)$ (Tab. 1).

For test surface $\mathrm{P}_{2}$ also no statistically significant relation was noted between $n_{d P}$ and $R^{2}$. The lowest values of the coefficient of determination $\left(R^{2}=\right.$ 0.9666) were obtained in April at $n_{d P}$ of 11 , while in July and September, at $n_{d P}$ equal to 10 , the values of $R^{2}$ were 0.9949 and 0.9888 . Whereas, in August, at the highest $n_{d P}\left(n_{d P}=15\right)$, one of the highest values of $R^{2}$ was obtained for $\mathrm{P}_{2}\left(R^{2}=0.9988\right)$ (Tab. 1).

In the case of test surface APB the lowest $n_{d P}$ occurred in April $\left(n_{d P}=5\right)$, when the value of $R^{2}$, describing the relation between $P_{d}$ and $O_{d o s}$, was the lowest among the months under analysis $\left(R^{2}=\right.$ 0.7544) (Tab. 1). However, in the following month, in 
Table 1. Calculated values of coefficients of determination $\left(R^{2}\right)$ describing monthly relations between diurnal sums of atmospheric precipitation and diurnal volumes of runoff from test surfaces, and critical values of those coefficients $\left(R_{\mathrm{kr}}^{2}\right)$

\begin{tabular}{|c|c|c|c|c|c|}
\hline \multirow{2}{*}{ Month } & \multirow{2}{*}{$\begin{array}{c}\text { Coefficient of } \\
\text { determination }\end{array}$} & \multicolumn{4}{|c|}{ Type of test surface } \\
\cline { 2 - 6 } & $R^{2}$ & 0.9851 & 0.9666 & 0.7544 & 0.9556 \\
\hline \multirow{2}{*}{$\mathrm{IV}$} & $R_{\mathrm{kr}}^{2}$ & 0.4998 & 0.3318 & 0.6577 & 0.6577 \\
\hline \multirow{2}{*}{$\mathrm{V}$} & $R^{2}$ & 0.9933 & 0.9796 & 0.8371 & 0.9920 \\
\cline { 2 - 6 } & $R_{\mathrm{kr}}^{2}$ & 0.3058 & 0.2830 & 0.2470 & 0.2830 \\
\hline \multirow{2}{*}{$\mathrm{VI}$} & $R^{2}$ & 0.9980 & 0.9936 & 0.9050 & 0.9990 \\
\cline { 2 - 6 } & $R_{\mathrm{kr}}^{2}$ & 0.3994 & 0.3994 & 0.3624 & 0.3624 \\
\hline \multirow{2}{*}{$\mathrm{VII}$} & $R^{2}$ & 0.9977 & 0.9949 & 0.9927 & 0.9618 \\
\cline { 2 - 6 } & $R_{\mathrm{kr}}^{2}$ & 0.3994 & 0.3624 & 0.3624 & 0.3624 \\
\hline \multirow{2}{*}{$\mathrm{VIII}$} & $R^{2}$ & 0.9978 & 0.9988 & 0.9860 & 0.9574 \\
\cline { 2 - 6 } & $R_{\mathrm{kr}}^{2}$ & 0.2470 & 0.2470 & 0.2470 & 0.2470 \\
\hline \multirow{2}{*}{$\mathrm{IX}$} & $R^{2}$ & 0.9559 & 0.9888 & 0.9591 & 0.9784 \\
\cline { 2 - 6 } & $R_{\mathrm{kr}}^{2}$ & 0.3318 & 0.3624 & 0.3058 & 0.3624 \\
\hline \multirow{2}{*}{$\mathrm{X}$} & $R^{2}$ & 0.9987 & 0.9998 & 0.9979 & 0.9989 \\
\cline { 2 - 6 } & $R_{\mathrm{kr}}^{2}$ & 0.3994 & 0.4998 & 0.3624 & 0.3994 \\
\hline \multirow{2}{*}{$\mathrm{XI}$} & $R^{2}$ & 0.9778 & 0.9905 & 0.9499 & 0.9582 \\
\cline { 2 - 6 } & $R_{\mathrm{kr}}^{2}$ & 0.4436 & 0.4998 & 0.3624 & 0.3994 \\
\hline
\end{tabular}

Source: own study.

which $n_{d P}$ was 15 , the value of $R^{2}$ was the second lowest value noted for test surface APB within the period studied $\left(R^{2}=0.8371\right)$. For the months in which the highest values of $R^{2}$ were obtained (October and July) the value of $n_{d P}$ was 10 in both cases.

Similarly, in the case of test surface AS the lowest values of $R^{2}$ were obtained both at the minimum and the maximum numbers of days with precipitation in a month. In April, when $n_{d P}$ was 5, the value of $R^{2}$ was 0.9556. In August, when 15 days with rainfall were recorded, the value of $R^{2}$ was 0.9574 . The highest values of $R^{2}$, close to 1 , were obtained at $n_{d P}$ of 9 and 10 (Tab. 1).

\section{MEAN VALUES AND MEDIANS OF RAINWATER RUNOFF COEFFICIENT FOR THE FOUR TEST SURFACES}

The obtained mean values and medians of the rainwater runoff coefficient are distinctly dependent on the type of test surface - a higher degree of surface imperviousness caused the obtainment of higher values of the runoff coefficient (Tab. 2).

The highest mean of the rainwater runoff coefficient, for the period of eight months $\left(\psi_{s r}\right)$, were obtained for the two roof surfaces $\mathrm{P}_{1}$ and $\mathrm{P}_{2}$. For each of those surfaces that value was 0.77 . A somewhat lower value was obtained for the third impervious surface AS $\left(\psi_{s r}=0.67\right)$, for which the mean value in a month $\left(\psi_{s}\right)$ was lower, over as many as five months, compared to the value of $\psi_{s}$ for $\mathrm{P}_{1}$ and $\mathrm{P}_{2}$, and during the whole eight-month period it was lower than that for at least one of the roof surfaces $\left(\mathrm{P}_{1}\right.$ and $\left.\mathrm{P}_{2}\right)$. Depending on the month, the medians of the coefficients of rainwater runoff from the test surfaces varied within the
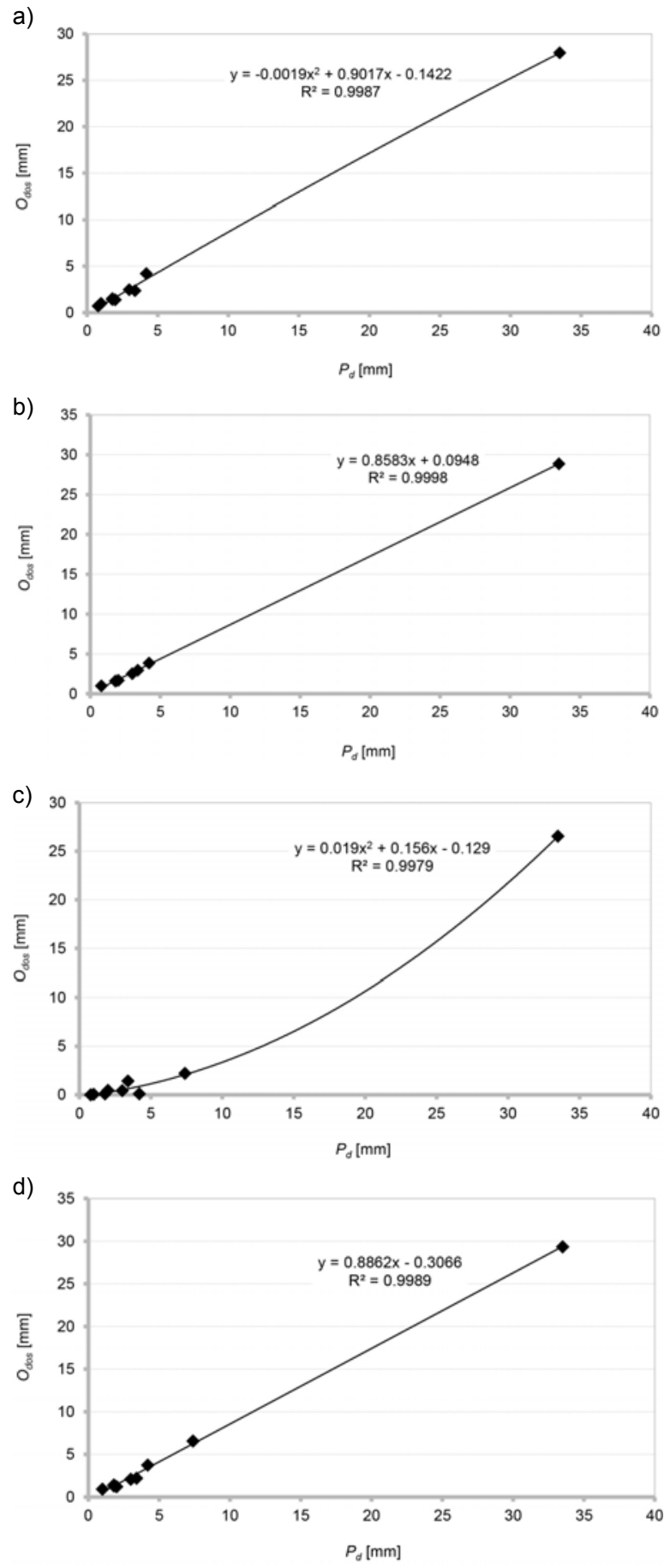

Fig. 1. Relation between diurnal sums of runoff $\left(O_{d o s}\right)$ from test surface and diurnal sums of atmospheric precipitation $\left(P_{d}\right)$ for test surfaces (October): a) $\mathrm{P}_{1}$, b) $\mathrm{P}_{2}$, c) APB, d) AS; source: own study

ranges of $0.67-0.91\left(\mathrm{P}_{1}\right), 0.70-0.89\left(\mathrm{P}_{2}\right), 0.04-0.36$ (APB) and 0.56-0.87 (AS) (Tab. 2).

The relation of the value of the maximum ranges of variability between minimum and maximum monthly values of the coefficient of rainwater runoff from the test surfaces is as follows: APB $>\mathrm{P}_{1}>\mathrm{AS}>$ $\mathrm{P}_{2}$, which in numerical notation is represented by the values: $0.40>0.34>0.33>0.30$ (Tab. 2 ). 
Table 2. Values of the rainwater runoff coefficient for the four test surfaces (for 8-month period of study)

\begin{tabular}{|l|c|c|c|c|}
\hline \multirow{2}{*}{ Parameter } & \multicolumn{4}{|c|}{ Type of test surface } \\
\cline { 2 - 5 } & $\mathrm{P}_{1}$ & $\mathrm{P}_{2}$ & $\mathrm{APB}$ & $\mathrm{AS}$ \\
\hline $\begin{array}{l}\text { Number of days with precipitation } \\
\left(n_{d P}\right)\end{array}$ & 81 & 82 & 87 & 81 \\
\hline Mean value $\left(\psi_{s r}\right)$ & 0.77 & 0.77 & 0.33 & 0.67 \\
\hline $\begin{array}{l}\text { Minimum monthly value from the } \\
\text { 8-month period }\left(\psi_{\text {smin }}\right)\end{array}$ & 0.57 & 0.60 & 0.13 & 0.54 \\
\hline $\begin{array}{l}\text { Maximum monthly value from } \\
\text { the 8-month period }\left(\psi_{\text {smax }}\right)\end{array}$ & 0.91 & 0.90 & 0.53 & 0.87 \\
\hline Median $\left(\psi_{m e}\right)$ & 0.83 & 0.85 & 0.06 & 0.69 \\
\hline $\begin{array}{l}\text { Minimum monthly median from } \\
\text { the 8-month period }\left(\psi_{\operatorname{memin}}\right)\end{array}$ & 0.67 & 0.70 & 0.04 & 0.56 \\
\hline $\begin{array}{l}\text { Maximum monthly median from } \\
\text { the 8-month period }\left(\psi_{\operatorname{memax}}\right)\end{array}$ & 0.91 & 0.89 & 0.36 & 0.87 \\
\hline
\end{tabular}

Source: own study.

\section{SIMILARITY OF THE RANGES OF VARIABILITY OF MEAN MONTHLY VALUES $\left(\psi_{s}\right)$}

The most similar ranges of variability of mean monthly values were obtained for the two roof surfaces $\mathrm{P}_{1}$ and $\mathrm{P}_{2}$ (Fig. 2a). Both for $\mathrm{P}_{1}$ and for $\mathrm{P}_{2}$ the lowest mean values of the rainwater runoff coefficient in a month were obtained in May: $\psi_{\text {smin }}=0.57$ for $\mathrm{P}_{1}$ and $\psi_{s \min }=0.60$ for $\mathrm{P}_{2}$. Also in May a low value of $\psi_{s}$ was obtained for test surface AS $\left(\psi_{s}=0.57\right)$ (Fig. 2b).

Among the four test surfaces the most individual range of variability of the mean value of the rainwater runoff coefficient in a month was displayed by test surface APB. The value of the coefficient for that sur-
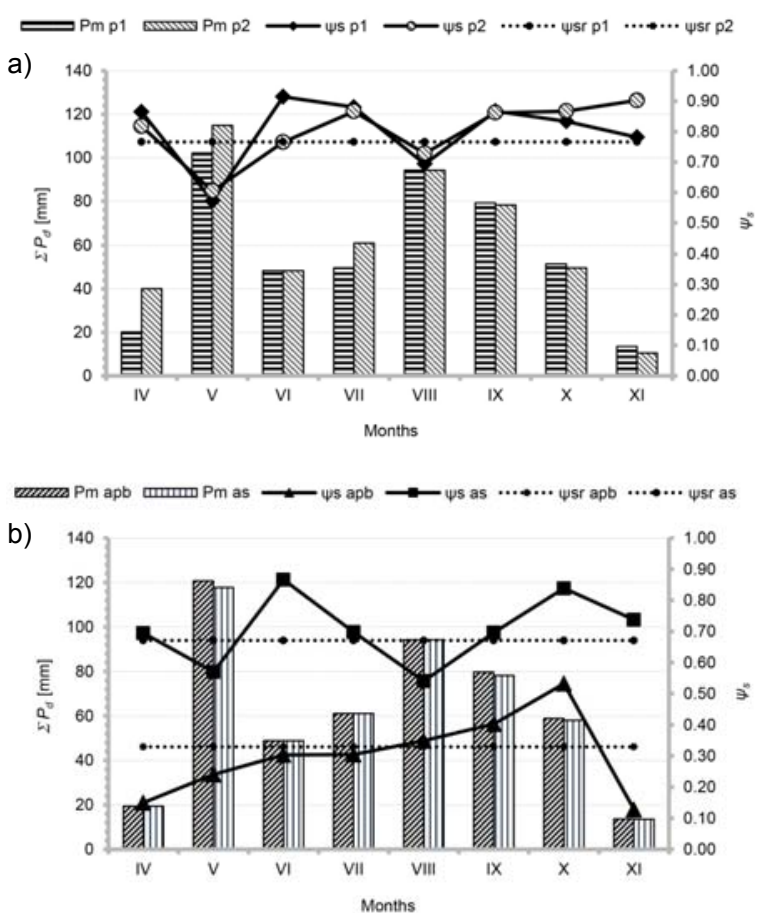

Fig. 2. Ranges of variability of mean values of rainwater runoff coefficient in a month $\left(\psi_{s}\right)$ from two roof surfaces: $\mathrm{P}_{1}$ and $\mathrm{P}_{2}$ (a) and two driveway surfaces: APB and AS (b) versus the monthly sums of precipitation $\left(\Sigma P_{d}\right)$ and versus the mean value of the runoff coefficient $\left(\psi_{s r}\right)$ calculated for the eight-month period; source: own study face was distinctly dependent on the occurrence of precipitation on earlier days. Comparison of the mean values of runoff coefficient in a month $\left(\psi_{s}\right)$ for the two driveway surfaces (APB and AS) demonstrated the occurrence of similar variability of the values of $\psi_{s}$, especially in the second half of the study period (Fig. 2b).

For the periods created by combining the months in the incremental manner smaller ranges of variability of the mean values $\left(\psi_{s}\right)$ were obtained for all the surfaces, and distinctly smaller in the case of surfaces $\mathrm{P}_{1}$ and $\mathrm{P}_{2}$. The difference between the maximum and the minimum mean values of rainwater runoff coefficient in a created periods for $\mathrm{P}_{1}$ was 0.21 , and for $\mathrm{P}_{2}$ 0.17 (Fig. 3a).

It appears important to note that after the period of 40 days the value of rainwater runoff coefficient stabilised and approached to the mean value $\left(\psi_{s r}\right)$. Furthermore, the value of the runoff coefficient for the 4-month period (April-July) attained a value similar to the mean value of the rainwater runoff coefficient for the 8-month period and that value changed only slightly during subsequent periods (Fig. 3).

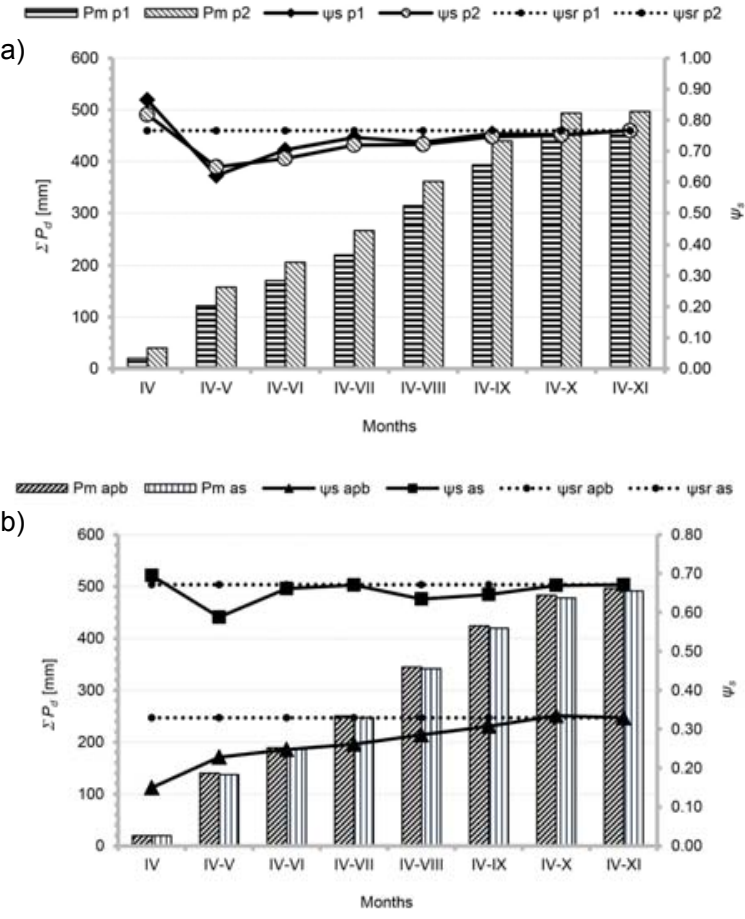

Fig. 3. Ranges of variability of mean values of rainwater runoff coefficient $\left(\psi_{s}\right)$ from two roof surfaces: $\mathrm{P}_{1}$ and $\mathrm{P}_{2}$ (a) and two driveway surfaces: APB and AS (b) in the created time periods versus the sums of precipitation $\left(\Sigma P_{d}\right)$ (calculated for the same time periods) and versus the mean value of the runoff coefficient $\left(\psi_{s r}\right)$ calculated for the eight-month period; source: own study

\section{DIURNAL MINIMUM AND MAXIMUM VALUES OF RAINWATER RUNOFF COEFFICIENTS}

During the whole study period the lowest minimum diurnal values of the rainwater runoff coefficient $\left(\psi_{d \text { min }}\right)$ were obtained for test surface APB. For test 
surface $\mathrm{P}_{1}$ a diurnal value $\left(\psi_{d \min }\right)$ equal to 0.00 was obtained 8 times. That result was obtained at low diurnal sums of precipitation $(0.10-0.50 \mathrm{~mm})$. For two months (June and October) higher minimum values were obtained ( 0.45 and $0.69 \mathrm{~mm}$, respectively). Similar results were obtained for test surface $\mathrm{P}_{2}$. Seven times $\psi_{d}$ was 0.00 at diurnal sums of precipitation within the range of $0.10-0.50 \mathrm{~mm}$. In the case of test surface AS values of the diurnal rainwater runoff coefficient equal to 0 were obtained 8 times. Differently than in the case of test surfaces $P_{1}$ and $P_{2}$, the value of $\psi_{d \min }$ for test surface AS in April was not 0.00 , but as in the case of the two roof surfaces the value of $\psi_{d \mathrm{~min}}$ in June was $>0$. Also in the case of the minimum values the semi-permeable test surface APB displayed its individual character compared to the impervious surfaces $\mathrm{P}_{1}, \mathrm{P}_{2}$ and AS. As many as 19 times the diurnal minimum values were 0.00 , and the remaining results of $\psi_{d}$ were values significantly lower than those obtained for the other test surfaces.

During the period of the study, for test surface $\mathrm{P}_{1}$ maximum diurnal values $\left(\psi_{d \max }\right)$ of 1.00 were obtained 11 times. Diurnal values $\psi_{d \max }<1$ were obtained in April and in November. For test surface $\mathrm{P}_{2}$ diurnal values $\psi_{d \max }$ equal to 1.00 were obtained only 5 times. An even lower result was obtained in the case of test surface AS. Diurnal values of $\psi_{d \max }$ equal to 1.00 were obtained only twice - in May and in November.

\section{DISCUSSION}

\section{RELATION BETWEEN DIURNAL SUMS OF PRECIPITATION AND VOLUME OF RAINWATER RUNOFF}

A distinct correlation was noted between the volume of rainwater runoff and the diurnal sums of precipitation in the case of all test surfaces. The high values of $R^{2}$ obtained indicate a positive correlation in the case of the diurnal runoff volumes and the diurnal sums of precipitation. In the case of test surface APB April was an exceptional month when a low value of $R^{2}(0.7544)$ was obtained. That was due to a small number of observations resulting from the start of the measurement cycle in that month (only five observations for test surface APB).

\section{SURFACE RUNOFF - RAINWATER RUNOFF COEFFICIENTS}

The study demonstrated that the volume of rainwater runoff is distinctly related with the kind of surface. The results are in conformance with the results of studies conducted both on experimental test surfaces [BRATTEBO, BоOTH 2003; COLLINS et al. 2008; GILBERT, ClausEN 2006] and in the area of urban catchment basins [GOLDSHLEGER et al. 2012; MELANEN, LAUKKANEN 1980; METSÄRANTA et al. 2005; VALTANEN et al. 2014].
The results obtained, in the form of rainwater runoff coefficients, display a certain analogy to the results obtained by VALTANEN et al. [2014]. The only difference is the scale of the research. The median of the rainwater runoff coefficient obtained in the study for test surface AS is similar to the median of rainwater runoff coefficient obtained by those authors for a catchment basin with a high degree of imperviousness (difference of 0.06). The results obtained - mean value $(0.67)$ and median $(0.69)$ - for test surface AS are considerably lower than the value of the runoff coefficient for a tarmac surface obtained by JAMES and THOMPSON [1997]. Those authors observed runoff volume from a tarmac surface equal to $100 \%$ of the precipitation, while our study on the test surfaces permitted the observation that only on two days the runoff from test surface AS was equal to $100 \%$ of the precipitation. Those results were obtained in May and in November, when the air temperature and the insolation were low, resulting in low evaporation and thus larger volumes of precipitation water runoff from the test surfaces.

Higher values of precipitation water runoff from a tarmac surface were obtained also by BRATTEBO, BoоTH [2003], who used the tarmac surface as a reference surface for results obtained for four permeable surfaces.

At the same time it was noted that at low diurnal sums of precipitation and higher air temperature occurring in the summer months the values of the rainwater runoff coefficient for the test surfaces were lower than in the autumn months, with lower air temperature. The higher air temperature and the level of insolation in the summer months caused heating up of the test surfaces, which was reflected in increased levels of surface evaporation. Water evaporation took place as a result of contact with the heated test surface, due to which reduced amounts of precipitation water flew to the measurement reservoir. These observations can be related to the conclusions presented by VALTANEN et al. [2014] in the aspect of the seasonal variation of values of the rainwater runoff coefficient. A periodic variation in the values of the rainwater runoff coefficient was found also, on the basis of a three-year study, by METSÄRANTA et al. [2005]. Whereas, GILBERT, CLAUSEN [2006] after a one-year study of the volume of precipitation water runoff from four garage driveways built of tarmac, paving blocks and gravel did not find any seasonal differences in relation to the values of the runoff coefficient.

\section{RUNOFF FROM SURFACE APB}

Among the measured data in the form of diurnal volumes of runoff it was observed that sometimes the same diurnal sum of atmospheric precipitation results in different volumes of surface runoff. The basic factor that affects the observed differences is an occurrence of precipitation on the preceding day or during several preceding days, reflected directly in the mois- 
ture of the surface. Collins et al. [2008], showed that surfaces built of concrete paving blocks that were moist at the moment of occurrence of precipitation retained $30 \%$ of the precipitation water, while dry surfaces were able to retain $50 \%$ of the precipitation water. The effect of preliminary wetting of a surface on the volume of surface runoff was observed to the greatest extent in the case of test surface APB. As an example, a $\psi_{s}$ value of 0.30 on the first day of precipitation increased to 0.89 after three days of continuous precipitation. The cause of the dynamic increase in the value of $\psi_{s}$ was water retention by the gravel material filling the open spaces in the openwork concrete plates due to the notable volumes of incoming precipitation water and, as a result, the reduction of the infiltration capacity of that test surface. Whereas, in the case of individual precipitation events test surface APB displayed a high ability of reducing the volume of surface runoff.

\section{NUMBER OF DAYS WITH PRECIPITATION NECESSARY FOR THE DETERMINATION OF THE VALUE OF THE COEFFICIENT OF RAINWATER RUNOFF FROM THE TEST SURFACES}

It was noted that for the periods created by the incremental addition of months after the 4-month period the value of the rainwater runoff coefficient stabilised and was equal to the mean value calculated for the entire period of observations. Whereas, during the first month of measurements, when only 7 measurements were made for $\mathrm{P}_{1}, 11$ for $\mathrm{P}_{2}$ and 5 each for APB and AS the mean value of the rainwater runoff coefficient calculated for that month differed the most from the mean value calculated after the 8-th month period of the study. Therefore, it can be concluded that it is possible to determine the minimum number of observations (number of days on which a measurement was made) at about 40 as the necessary number for the determination of the value of the rainwater runoff coefficient for various types of surfaces.

\section{CONCLUSIONS}

Although the first period of experimentation lasted eight months and is currently continued, it was possible to identify the differences among the four test surfaces in terms of the volume of surface runoff in relation to the diurnal and monthly sums of precipitations. The study described above permitted the formulation of the following conclusions.

1. The number of days with precipitation in a month had no effect on the value of the coefficient of determination describing the relation between the diurnal sums of precipitation and the diurnal volumes of precipitation water runoff from the test surfaces.

2. Among the four test surfaces the lowest value of the rainwater runoff coefficient was obtained for surface APB. As a direct consequence of that, surface
APB reduced the volume of surface runoff to the greatest extent relative to a day and a month.

3. A distinct effect of several-day rainfalls on an increase in the value of the rainwater runoff coefficient was noted in the case of test surface APB.

4. The study permitted the estimation of the minimum period or - more accurately - the number of days with precipitation necessary for the determination of the value of the rainwater runoff coefficient for a given type of surface. That number was determined at approximately 40 days on which precipitation occurred. After that period a stabilisation of the value of the rainwater runoff coefficient was observed.

\section{REFERENCES}

ARnOld Ch.L.Jr, GibBons C.J. 1996. Impervious surface coverage: The emergence of a key environmental indicator. Journal of the American Planning Association. Vol. 62. No. 2 p. $243-258$

BARron O.V., Pollock D., DAwES W. 2011. Evaluation of catchment contributing areas and storm runoff in flat terrain subject to urbanisation. Hydrology and Earth System Sciences. No. 15 p. 547-559.

Blair A., Lovelace S., Sanger D., Holland A.F., VanDIVER L., WHITE S. 2014. Exploring impacts of development and climate change on stormwater runoff. Hydrological Processes. Vol. 28. Iss. 5 p. 2844-2854.

Brattebo B.O., Booth D.B. 2003. Long-term stormwater quantity and quality performance of permeable pavement systems. Water Research. Vol. 37. Iss. 18 p. 4369 4376.

BRW 2012. Ocena aktualności studium uwarunkowań i kierunków zagospodarowania przestrzennego Wrocławia oraz miejscowych planów zagospodarowania przestrzennego na obszarze Wrocławia z maja 2012 r. [Evaluation of the study of Wrocław spatial development and local developments plans from May 2012]. Wrocław. Biuro Rozwoju Wrocławia pp. 50.

Burns D., Vitvar T., McDOnNell J., HassetT J., DunCAN J., Kendall C. 2005. Effects of suburban development on runoff generation in the Croton River basin, New York, USA. Journal of Hydrology. Vol. 311 p. 266-281.

BZYMEK B., JAROSIŃSKA E. 2012. Wpływ uszczelnienia powierzchni zlewni na odpływ wód deszczowych [The effect of surface seal catchment on the size of storm water runoff]. Czasopismo Techniczne, Środowisko. Vol. 109. Iss. 1-Ś p. 41-57.

Collins K.A., Hunt W.F., Hathaway J.M. 2008. Hydrologic comparison of four types of permeable pavement and standard asphalt in eastern North Carolina. Journal of Hydrologic Engineering. Vol. 13. Iss. 12 p. 11461157.

Dubicki A., Dubicka M., Szymanowski M. 2002. Klimat Wrocławia. W: Informator o stanie środowiska Wrocławia 2002 [The climate of Wrocław. In: Report of the environmental conditions of Wrocław 2002]. Ed. K. Smolnicki, M. Szykasiuk. Wrocław. Wydaw. Dolnośląska Fundacja Ekorozwoju p. 9-25.

FERGUSON B.K., SUCKLING P.W. 1989. Variations in precipitation and runoff in an urbanizing watershed. In: Proceedings of the 1989 Georgia Water Resources Conference. Ed. K.J. Hatcher. Institute of Natural Resources, University of Georgia p. 145-148. 
Gilbert J.K., Clausen J.C. 2006. Stormwater runoff quality and quantity from asphalt, paver, and crushed stone driveways in Connecticut. Water Research. Vol. 40. Iss. 4 p. $826-832$.

Goldshleger N., Karnibad L., Shoshany M., Asaf L. 2012. Generalising urban runoff and street network density relationship: A hydrological and remote-sensing case study in Israel. Urban Water Journal. Vol. 9. Iss. 3 p. 189-197.

JAMES W., ThOMPSON M.K. 1997. Contaminants from four new pervious and impervious pavements in a parking lot. In: Advances in Modeling the management of stormwater impacts. Vol. 2. Ed. W. James. Guelph, Canada. CHI p. 207-222.

JenNings D.B., JaRnAGIN S.T. 2002. Changes in anthropogenic impervious surfaces, precipitation and daily streamflow discharge: a historical perspective in a midatlantic subwatershed. Landscape Ecology. Vol. 17. Iss. 5 p. 471-489.

Larsen A.N., Gregersen I.B., Christensen O.B., Linde J.J., Mikkelsen P.S. 2009. Potential future increase in extreme one-hour precipitation events over Europe due to climate change. Water Science and Technology. Vol. 60. Iss. 9 p. 2205-2216.
Melanen M., LAUKKANEN R. 1980. Analysis of rainfallrunoff relationships in Finnish urban test basins. In: Proceedings of the Helsinki Symposium, June 1980. IAHS-AISH Publ. No. 130 p. 43-48.

Metsäranta N., Kotola J., Nurminen J. 2005. Effects of urbanization on runoff water quantity and quality: Experiences from test catchments in Southern Finland. International Journal of River Basin Management. Vol. 3 Iss. 3 p. 229-234.

SillanpäÄ N., KoIVUSAlo H. 2015. Impacts of urban development on runoff event characteristics and unit hydrographs across warm and cold seasons in high latitudes. Journal of Hydrology. Vol. 521. Iss. 2 p. 328340.

Valtanen M., SillanpäÄ N., Setälä H. 2014. Effects of land use intensity on stormwater runoff and its temporal occurrence in cold climates. Hydrological Processes. Vol. 28. Iss. 4 p. 2639-2650.

VlČKOVÁ M., NechVÁtal M., Soukup M. 2009. Annual runoff coefficient in the Cerhovický Stream catchment. Journal of Water and Land Development. Vol. 13b p. $41-56$.

\section{Alicja ROMANIAK}

\section{Ocena zależności między opadem atmosferycznym a spływem powierzchniowym wody opadowej z różnych powierzchni miejskich}

\section{STRESZCZENIE}

Zależność między sumą dobową opadu atmosferycznego a dobową objętością spływu powierzchniowego z czterech eksperymentalnych powierzchni utwardzonych była przedmiotem badań pilotażowych prowadzonych na terenie Wydziałowego Obserwatorium Agro- i Hydrometeorologii we Wrocławiu (Wrocław-Swojec). Wybór i budowa powierzchni eksperymentalnych zostały poprzedzone inwentaryzacją pokrycia powierzchni utwardzonych w obrębie wrocławskiego osiedla mieszkaniowego o zabudowie wielorodzinnej wysokiej, będącego druga, poza obszarem Obserwatorium, lokalizacja, w której prowadzone są badania. Dwie z powierzchni eksperymentalnych stanowia powierzchnie dachowe $\mathrm{P}_{1}$ i $\mathrm{P}_{2}$ pokryte papą termozgrzewalna, natomiast kolejne dwie to powierzchnia APB wykonana $\mathrm{z}$ ażurowych płyt betonowych wypełnionych materiałem żwirowym oraz powierzchnia asfaltowa AS. Badania pilotażowe wykonywano w okresie od kwietnia do listopada 2014 roku. W tym czasie, w zależności od rodzaju powierzchni doświadczalnej przeanalizowano od 81 do 87 dni, w których wystąpił opad atmosferyczny. Wartości średnie współczynników spływu powierzchniowego z okresu ośmiu miesięcy wyniosły: $0,77,0,77,0,33$ i 0,67 odpowiednio dla $\mathrm{P}_{1}, \mathrm{P}_{2}$, APB i AS. Zakres zmienności średnich wartości współczynników spływu z powierzchni doświadczalnych w miesiącu $\left(\psi_{s}\right)$ przedstawia następująca zależność: APB > $\mathrm{P}_{1}>\mathrm{AS}>\mathrm{P}_{2}$. Na podstawie badań nie stwierdzono bezpośredniego wpływu liczby dni z opadem w ciągu miesiąca na wartość współczynnika determinacji opisującego zależność między sumami dobowymi opadu i dobowymi objętościami spływu wody opadowej z powierzchni doświadczalnych.

Słowa kluczowe: nieprzepuszczalność, opad atmosferyczny, pokrycie powierzchni, współczynniki splywu powierzchniowego 